Article

\title{
Role of transition-metal electrocatalysts for oxygen evolution with Si-based photoanodes
}

\author{
Rajender Boddula a,, , Guancai Xie a,b,, , Beidou Guo a,b, Jian Ru Gong a,b,* \\ a Chinese Academy of Sciences (CAS) Center for Excellence in Nanoscience, CAS Key Laboratory of Nanosystem and Hierarchy Fabrication, National Center \\ for Nanoscience and Technology, Beijing 100190, China \\ b University of Chinese Academy of Sciences, Beijing 100049, China
}

\section{A R T I C L E I N F O}

\section{Article history:}

Received 28 February 2020

Accepted 23 March 2020

Available online 5 April 2021

\section{Keywords:}

Solar water splitting

Artificial photosynthesis

Oxygen evolution reaction

Photoanode

Interfacial engineering

Transition-metal electrocatalyst

\begin{abstract}
A B S T R A C T
A comprehensive understanding of the role of the electrocatalyst in photoelectrochemical (PEC) water splitting is central to improving its performance. Herein, taking the Si-based photoanodes $\left(\mathrm{n}^{+} \mathrm{p}-\mathrm{Si} / \mathrm{SiO}_{x} / \mathrm{Fe} / \mathrm{FeO}_{x} / \mathrm{MOOH}, \mathrm{M}=\mathrm{Fe}, \mathrm{Co}, \mathrm{Ni}\right)$ as a model system, we investigate the effect of the transition-metal electrocatalysts on the oxygen evolution reaction (OER). Among the photoanodes with the three different electrocatalysts, the best OER activity, with a low-onset potential of $\sim 1.01$ $V_{\mathrm{RHE}}$, a high photocurrent density of $24.10 \mathrm{~mA} \mathrm{~cm}^{-2}$ at $1.23 V_{\mathrm{RHE}}$, and a remarkable saturation photocurrent density of $38.82 \mathrm{~mA} \mathrm{~cm}^{-2}$, was obtained with the $\mathrm{NiOOH}$ overlayer under AM 1.5G simulated sunlight $\left(100 \mathrm{~mW} \mathrm{~cm}^{-2}\right)$ in $1 \mathrm{M} \mathrm{KOH}$ electrolyte. The optimal interfacial engineering for electrocatalysts plays a key role for achieving high performance because it promotes interfacial charge transport, provides a larger number of surface active sites, and results in higher OER activity, compared to other electrocatalysts. This study provides insights into how electrocatalysts function in water-splitting devices to guide future studies of solar energy conversion.
\end{abstract}

(C) 2021, Dalian Institute of Chemical Physics, Chinese Academy of Sciences. Published by Elsevier B.V. All rights reserved.

\section{Introduction}

Photoelectrochemical (PEC) water splitting is an intriguing way to convert solar energy into a sustainable, green, and storable hydrogen fuel [1]. The key issue for water splitting is the kinetic bottleneck of the four electron-hole processes during the water oxidation half-reaction, i.e., the oxygen evolution reaction (OER) [2-5]. Like photocatalytic energy conversion [6-9], high-efficiency PEC water splitting devices also require the modification of electrocatalysts on semiconductors. Silicon is a promising semiconductor for achieving PEC water splitting commercialization owing to its ideal bandgap $(\sim 1.1 \mathrm{eV})$, high theoretical solar-to-hydrogen efficiency of $41 \%$, and abundance [1,10-13]. Unfortunately, bare Si has a large overpotential for the OER because of its poor surface properties and because it is photocorroded easily owing to its intrinsic instability under aqueous conditions, especially at high $\mathrm{pH}[14]$.

An oxygen evolution catalyst (OEC) generally improves the OER performance of $\mathrm{Si}$ photoanodes by reducing the OER overpotential [15-18], engineering the photovoltage of the photoanodes via passivation of surface states of the semiconductor or formation of junctions with the light absorber [12,19-21], or serving as a corrosion-resistant Si protection layer [22-24]. Noble metal oxides are traditional materials

\footnotetext{
* Corresponding author. Tel: +86-10-82545649; Fax: +86-10-62656765; E-mail: gongjr@nanoctr.cn

† These authors contributed equally to this paper.

This work was supported by the Strategic Priority Research Program of CAS (XDB36000000), National Natural Science Foundation of China (21422303, 21573049, 21872043, 22002028), Beijing Natural Science Foundation (2142036), Youth Innovation Promotion Association of CAS, the Belt and Road Special Program of CAS, and CAS President's International Fellowship Initiative.

DOI: 10.1016/S1872-2067(20)63647-6 | http://www.sciencedirect.com/journal/chinese-journal-of-catalysis | Chin. J. Catal., Vol. 42, No. 8, August 2021
} 
applied as OECs but suffer from scarcity and high cost, severely restricting their large-scale practical applications. First-row transition metal oxyhydroxides $(\mathrm{MOOH}, \mathrm{M}=\mathrm{Fe}, \mathrm{Co}, \mathrm{Ni})$ have been developed recently as highly efficient electrocatalyst layers for some semiconductor photoanodes in water splitting devices owing to their eco-friendliness, remarkable catalytic performance, high abundance, high optical transparence, and good stability in alkaline electrolytes [25-30]. MOOH layers in these photoelectrodes can act as OER electrocatalysts to accelerate reaction kinetics, as hole collectors, as passivation layers to passivate the surface states of semiconductors, and as protection layers to suppress corrosion of the semiconductors [31-34]. Our previous work reported on FeOOH modified $\mathrm{n}^{+} \mathrm{p}-\mathrm{Si} / \mathrm{SiO}_{x} / \mathrm{M} / \mathrm{MO}_{x}$ photoanodes, which demonstrated a synergistic contribution between $\mathrm{MO}_{x}$ and $\mathrm{FeOOH}$ that facilitates the increase in the conductivity of the electrode, hole accumulation ability, interfacial charge transfer, and electrode stability [23]. In addition, due to the high work function of MOOH materials, the photovoltage of semiconductor photoelectrodes can also be increased by the modification of the $\mathrm{MOOH}$ layer on the surface [35]. Also, Hill et al. introduced an active cocatalyst, $\mathrm{CoOOH}$, electrodeposited on n-Si/Co photoanodes (n-Si/SiO $/ \mathrm{Co} / \mathrm{CoOOH}$ ), creating an inhomogeneous barrier height with a higher photovoltage [36]. Otherwise, the electrochemical deposition approach has attracted considerable attention for depositing OECs owing to its simplicity and cost effectiveness [22,23,36], as well as its suitability for large-scale practical applications, compared to other deposition techniques, such as atomic layer deposition, sputtering, and chemical vapor deposition, which commonly need expensive instruments and time-consuming processing [20,37-40]. However, the complex OEC structure formed by electrochemical deposition makes a clear and comprehensive mechanism explanation difficult $[34,36,41]$.

In this study, we investigate the effect of transition-metal OECs on the OER performance using Si-based photoanodes as a model system $\left(\mathrm{n}^{+} \mathrm{p}-\mathrm{Si} / \mathrm{SiO}_{x} / \mathrm{Fe} / \mathrm{FeO}_{x} / \mathrm{MOOH}(\mathrm{M}=\mathrm{Fe}, \mathrm{Co}, \mathrm{Ni})\right.$ ). Among the photoanodes with different OECs, the one with the $\mathrm{NiOOH}$ overlayer delivered the best OER activity with a high photocurrent density of $24.1 \mathrm{~mA} \mathrm{~cm}^{-2}$ at $1.23 \mathrm{~V}_{\mathrm{RHE}}$, a low-onset potential of $\sim 1.01 V_{\mathrm{RHE}}$, a saturation photocurrent density of $38.82 \mathrm{~mA} \mathrm{~cm}^{-2}$, and a $75 \mathrm{~h}$ stability under AM $1.5 \mathrm{G}$ simulated sunlight $\left(100 \mathrm{~mW} \mathrm{~cm}^{-2}\right)$ in $1 \mathrm{M} \mathrm{KOH}$ electrolyte. Moreover, the underlying mechanism will be explored to highlight the significance of interfacial engineering to the efficient functioning of electrocatalysts.

\section{Experimental}

\subsection{Photoanodes fabrication}

Polycrystalline $\mathrm{n}^{+} \mathrm{p}-\mathrm{Si}$ photoabsorbers with an anti-reflection layer on the $\mathrm{n}^{+-} \mathrm{Si}$ emitter side were purchased from LDK Solar Co. Ltd., and the as-received substrate was cleaved into required pieces and then were rinsed with acetone, isopropyl alcohol and deionized water (DI water, Milli-Q $18.2 \mathrm{M} \Omega \mathrm{cm}$ ) with ultrasonic agitation, each for $5 \mathrm{~min}$, in suc- cession. Immediately prior to Fe film coating on the p-side of the $n^{+} p$-Si substrate, the $p$-side was etched in buffered HF $(10 \%$ in volume) for 20s (the emitter side was protected by the $\mathrm{SiN}_{\mathrm{x}}$ layer), rinsed with DI water, dried with $\mathrm{N}_{2}$ gas, fixed on the sample holder using the Kapton tape, and finally loaded into the vacuum chamber of the thermal evaporation system (ZHD-300, Technol Science Co., Ltd) for metal film deposition of required thickness at the rate of $\sim 0.1 \AA \mathrm{s}^{-1}$, keeping the substrate temperature at $150{ }^{\circ} \mathrm{C}$. After thermal deposition of the $\mathrm{Fe}$ film, the silver electrodes at the emitter side of the $n^{+} p-S i$ substrate were adhered to the transparent indium-doped tin oxide (ITO) coated conducting glass, which acts as a transparent conductor for the PEC test, supports and protects the emitter against contacting with solution, by rubbing the indium-gallium (InGa) eutectic. To prepare the electrodes, one strip of the copper tape was inserted into a polytetrafluoroethylene tube, and the other strip was fixed on the outer wall of this tube. The two strips of the copper tapers were adhered to the ITO glass and metal film by InGa, as the electrical wires of working electrodes for PEC test and electrodeposition of $\mathrm{MOOH}(\mathrm{M}=\mathrm{Fe}, \mathrm{Co}, \mathrm{Ni})$, respectively. After that, the entire assembly was encased by epoxy (Hysol 9460F) to avoid the leakage of electrolyte and 704 silica gel was used as a second protecting layer on epoxy. The free ends of these two strips of the copper tapes were used to connect power source to apply the external voltage.

\subsection{Activation of the $n^{+} p-\mathrm{Si} / \mathrm{SiO} \times \mathrm{Fe}\left(n^{+} p-\mathrm{Si} / \mathrm{SiO} / \mathrm{aFe}\right)$}

Activation of the Fe metal film on the $\mathrm{n}^{+} \mathrm{p}-\mathrm{Si} / \mathrm{SiO}_{x} / \mathrm{Fe}$ working photoelectrode was done by potential cycling between -0.3 to $1.6 \mathrm{~V}$ versus saturated calomel electrode (SCE) by twenty consecutive $\mathrm{CV}$ scans at the sweep rate of $50 \mathrm{mV} \mathrm{s}^{-1}$ with $\mathrm{Pt}$ sheet as counter electrode in a three-electrode setup in $1.0 \mathrm{M}$ $\mathrm{KOH}$, using Zahner Zennium electrochemical workstation under 1 Sun irradiation.

\subsection{Electrochemical deposition of $\mathrm{MOOH}$ overlayer on the $n^{+} p-\mathrm{Si} / \mathrm{SiO}_{x} / \mathrm{aFe}$}

Lastly, MOOH (M= Fe, Co, Ni) film was electrochemical deposited on the $n^{+} p-S i / S i O_{x} / a F e$ [1] by a facile cathodic-electrodeposition approach using an electrochemical workstation (CHI760E, China) in a three-electrode setup with Pt sheet and SCE as the counter and reference electrodes by applying cathodic potential of $-1.0 \mathrm{~V}$ in electrolyte containing $30 \mathrm{mM}$ metal nitrate $\left[\mathrm{Fe}\left(\mathrm{NO}_{3}\right)_{3} \cdot 9 \mathrm{H}_{2} \mathrm{O}, \mathrm{Co}\left(\mathrm{NO}_{3}\right)_{2} \cdot 6 \mathrm{H}_{2} \mathrm{O}\right.$, $\mathrm{Ni}\left(\mathrm{NO}_{3}\right)_{2} \cdot 6 \mathrm{H}_{2} \mathrm{O}$ ] for different periods (100 s to $500 \mathrm{~s}$ ).

All of the electrodes were $\sim 1 \mathrm{~cm}^{2}$ in area unless specified otherwise. To assure the reproducibility of the results, at least twenty electrodes of each type were fabricated and tested in this work. All electrodes show similar characteristics and activity, and the representative data are reported.

\subsection{Characterization}

The morphologies and elemental compositions were recorded using ultrahigh-resolution field-emission scanning elec- 
tron microscope (FESEM, Hitachi-SU8220, Japan) at the accelerating voltage of $10 \mathrm{kV}$. The chemical compositions of the surfaces were scrutinized by ultrahigh vacuum VG ESCALAB 210 $\mathrm{X}$-ray photoelectron spectrometer (XPS) equipped with a multi-channel detector. The spectra were excited using monochromatic $\mathrm{Al} \mathrm{K \alpha}(1486.6 \mathrm{eV})$ source radiation.

\subsection{PEC measurements}

Electrochemical (EC) and PEC measurements were carried out using an electrochemical workstation (Zahner Zennium, Germany) in a typical three-electrode configuration with the prepared photoanode as the working electrode, Pt sheet as a counter electrode, SCE as a reference electrode, and 1.0 M KOH $(\mathrm{pH}=13.6)$ as the electrolyte. The light source is a $500 \mathrm{~W}$ Xenon lamp equipped with an AM 1.5G filter (CEL-S500, Au-light Co., Ltd.), and the light density was calibrated to be $100 \mathrm{~mW} \mathrm{~cm}^{-2}(1$ Sun). All measured potentials against SCE were converted to the reversible hydrogen electrode (RHE) scale according to the Nernst equation: $E_{\mathrm{RHE}}=E_{\mathrm{SCE}}+0.244 \mathrm{~V}+0.059 \times \mathrm{pH}$. All potentials were referred to the RHE without specification. The photocurrent versus potential $(\mathrm{U}-V)$ curves were recorded between 0.5 and $2.4 \mathrm{~V}$ versus RHE ( $\left.V_{\mathrm{RHE}}\right)$ in $1.0 \mathrm{M} \mathrm{KOH}$ at the scan rate of $50 \mathrm{mV} \mathrm{s}^{-1}$. Onset potential was measured at $5.5 \mathrm{~mA} \mathrm{~cm}-2$. Chronoamperometric measurements were recorded at the applied potential of $1.06 V_{\text {RHE. }} \mathrm{n}^{+} \mathrm{p}-\mathrm{Si} / \mathrm{SiO}_{x} / \mathrm{Fe}$ electrodes were activated by $20 \mathrm{CV}$ sweep cycles at the scan rate of $50 \mathrm{mV} \mathrm{s}^{-1}$. The applied bias photon-to-current efficiency (ABPE) of the photoanode was calculated from the $J-V$ curve under irradiation [2]. Tafel slopes were calculated from the $J-V$ measurements at $50 \mathrm{mV} \mathrm{s}^{-1}$ scan rate at the current density range of 1-10 mA $\mathrm{cm}^{-2}$. Faradaic efficiency for photoelectrochemically produced oxygen was analyzed by a gas chromatograph (GC9790II) with thermal conductivity detector. The electrochemically active surface area (ECSA) of photoelectrodes was estimated by measuring the double-layer capacitance $\left(C_{d l}\right)$ using scan rate dependence of CVs and their CV potential window of 0.2-0.3 V versus SCE in $1 \mathrm{M} \mathrm{KOH}$. $C_{d l}$ was determined by plotting the current density $\left(j_{\mathrm{a}}-j_{\mathrm{c}}\right)$ at $0.25 \mathrm{~V}$ versus SCE against the scan rate. The scan rates were $20,40,60,80$ and $100 \mathrm{mV} \mathrm{sec}^{-1}$. The slope is twice of the $C_{d l}$ is equal to the ECSA. Electrochemical impedance spectroscopy (EIS) data were collected at $1.23 V_{\text {RHE }}$ in the sweeping frequency of $0.1 \mathrm{~Hz}-100 \mathrm{kHz}$. The value of the charge transfer resistance $\left(R_{c t}\right)$ of the photoelectrodes was determined by ZsimpWin software simulations.

\section{Results and discussion}

A scheme of how the $\mathrm{MOOH}(\mathrm{M}=\mathrm{Fe}, \mathrm{Co}, \mathrm{Ni})$ overlayer is integrated on the polycrystalline $\mathrm{n}^{+} \mathrm{p}-\mathrm{Si}$ substrate through a partially activated $\mathrm{Fe}\left(\mathrm{Fe} / \mathrm{FeO}_{x}\right.$, denoted as aFe hereafter) interlayer is shown in Fig. 1a. In this photoanode, a Fe thin film was first deposited on the p-side of the $\mathrm{n}^{+} \mathrm{p}-\mathrm{Si} / \mathrm{SiO}_{x}$ substrate using thermal evaporation to make a highly electrically conductive contact. Then, the Fe film was partially oxidized to form a thin $\mathrm{FeO}_{x}$ layer on its surface by electrochemical activation in an alkaline electrolyte. Finally, the $\mathrm{MOOH}$ overlayer was electrochemically deposited onto the $\mathrm{n}^{+} \mathrm{p}-\mathrm{Si} / \mathrm{SiO}_{x} / \mathrm{aFe}$ surface at optimized conditions (see details in the Experimental Section, Supporting Information). The cross-sectional scanning electron microscopy (SEM) image of the $\mathrm{n}^{+} \mathrm{p}-\mathrm{Si} / \mathrm{SiO}_{x} / \mathrm{aFe} \mathrm{NiOOH}$ anode shown in Fig. $1 \mathrm{~b}$ displays that the aFe interlayer and the typical $\mathrm{NiOOH}$ overlayer have intimate contact at the interface, both with a thickness of $\sim 100 \mathrm{~nm}$. The chemical states of $\mathrm{Ni}, \mathrm{Fe}$, and 0 elements of the anode surface were analyzed by X-ray photoelectron spectroscopy (XPS) (Fig. S1 and Fig. 1c). The peak centered at $\sim 855.9 \mathrm{eV}$, with an associated satellite peak at $\sim 861.7 \mathrm{eV}$, can be assigned to $\mathrm{Ni} 2 p_{3 / 2}$ of $\mathrm{NiO}_{x} \mathrm{H}_{y}$ with the $\mathrm{Ni}^{3+}$
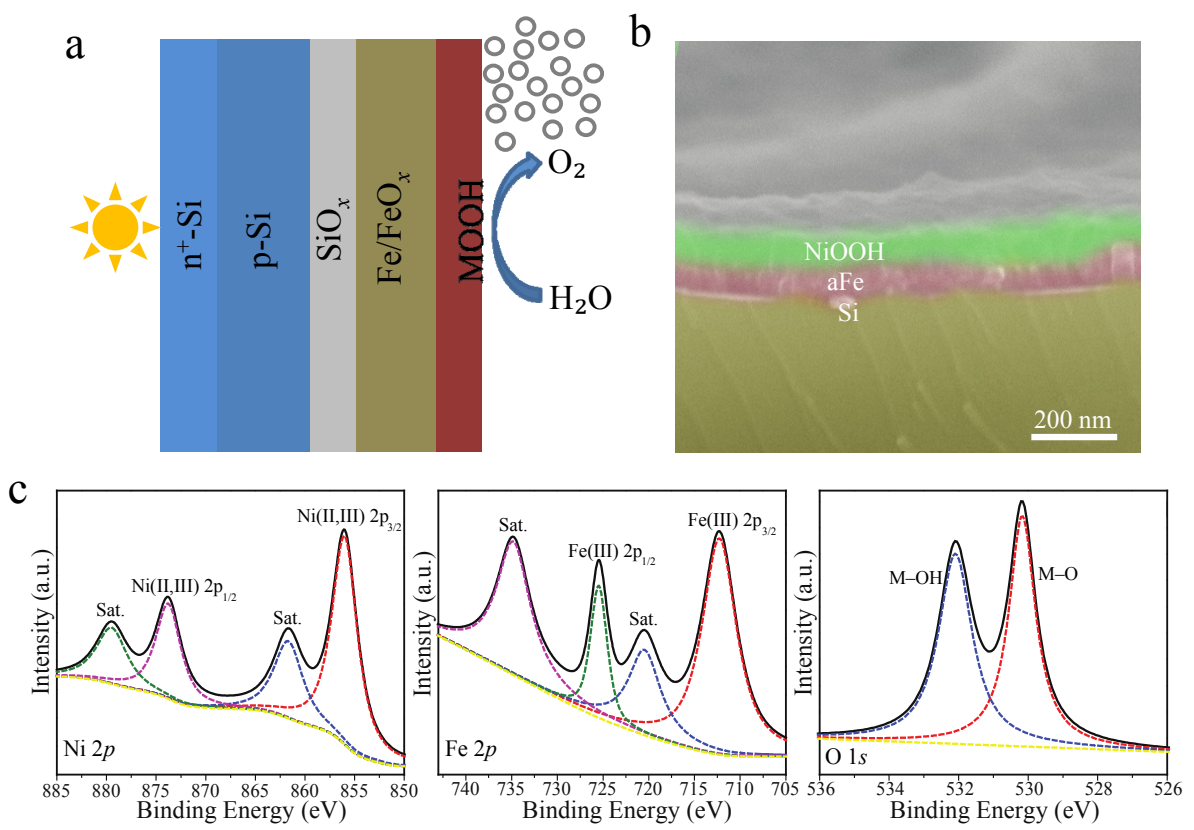

Fig. 1. (a) Schematic configuration of $\mathrm{n}^{+} \mathrm{p}-\mathrm{Si} / \mathrm{SiO}_{x} / \mathrm{aFe}: \mathrm{MOOH}(\mathrm{M}=\mathrm{Fe}, \mathrm{Co}, \mathrm{Ni}$ ) photoanodes; (b) cross-sectional SEM image and (c) XPS profiles of Ni $2 p$ $\mathrm{Fe} 2 p$, and $01 s$ for the $\mathrm{n}^{+} \mathrm{p}-\mathrm{Si} / \mathrm{SiO}_{x} / \mathrm{aFe}: \mathrm{NiOOH}$ photoanode. 
valence state $[22,23,39,42]$. For the Fe $2 p$ spectrum, two core-level peaks of $\mathrm{Fe} 2 p_{3 / 2}$ at $712.2 \mathrm{eV}$ and $\mathrm{Fe} 2 p_{1 / 2}$ at $725.4 \mathrm{eV}$ are present, implying the existence of $\mathrm{FeOOH}$ with the $\mathrm{Fe}^{3+}$ oxidation state [43]. Moreover, the corresponding SEM mapping of $\mathrm{Fe}, \mathrm{Ni}$, and $\mathrm{O}$ for the $\mathrm{n}^{+} \mathrm{p}-\mathrm{Si} / \mathrm{SiO}_{x} / \mathrm{aFe} \mathrm{NiOOH}$ sample (Fig. S2) shows that the elements $\mathrm{Fe}, \mathrm{Ni}$, and $\mathrm{O}$ are all well dispersed in the $\mathrm{n}^{+} \mathrm{p}-\mathrm{Si} / \mathrm{SiO}_{x} / \mathrm{aFe}: \mathrm{NiOOH}$. The uniform distribution of $\mathrm{Fe}$ on the surface of the $\mathrm{n}^{+} \mathrm{p}-\mathrm{Si} / \mathrm{SiO}_{x} / \mathrm{aFe}: \mathrm{NiOOH}$ clearly demonstrates the doping of $\mathrm{Fe}$ in the $\mathrm{NiOOH}$ overlayer. These results imply that the Fe ions in the interlayer dissolve, diffuse, and deposit on the overlayer during the $\mathrm{NiOOH}$ electrochemical deposition process since the Fe signal from the aFe interlayer cannot be probed by XPS through the $\sim 100 \mathrm{~nm}$ thick, relatively dense overlayer due to the limited XPS detection depth [39,44,45]. The Raman spectra of the $\mathrm{n}^{+} \mathrm{p}-\mathrm{Si} / \mathrm{SiO}_{x} / \mathrm{aFe}: \mathrm{NiOOH}$ photoanode also confirm the existence of $\mathrm{Ni}-\mathrm{Fe}$ oxide/(oxy)hydroxide (Fig. S3). The $01 s$ spectrum of the $\mathrm{n}^{+} \mathrm{p}-\mathrm{Si} / \mathrm{SiO}_{x} / \mathrm{aFe}: \mathrm{NiOOH}$ (Fig. 1c) shows two distinctive peaks located at 530.1 and $532.1 \mathrm{eV}$ that are attributed to metal-oxide (M-O) and metal-hydroxyl (M-OH) binding energies, respectively $[46,47]$. The ratio of the $\mathrm{O}^{2-}$ and $\mathrm{OH}^{-}$peak areas was estimated to be 1.1 , which is close to the theoretical ratio of 1 between $\mathrm{O}^{2-}$ and $\mathrm{OH}^{-}$in the metal oxyhydroxide MOOH [48]. The outcomes of XPS and Raman spectra analysis indicate the existence of $\mathrm{NiOOH}$ and $\mathrm{FeOOH}$ that could be integrated as $\mathrm{Fe}_{1-x} \mathrm{Ni}_{x} \mathrm{OOH}$ in the anode by mutual doping between the aFe and NiOOH OECs $[23,25,49]$. Besides $\mathrm{n}^{+} \mathrm{p}-\mathrm{Si} / \mathrm{SiO}_{x} / \mathrm{aFe}: \mathrm{NiOOH}$, the $\mathrm{n}^{+} \mathrm{p}-\mathrm{Si} / \mathrm{SiO}_{x} / \mathrm{aFe}: \mathrm{MOOH}$ (M=Fe, Co) photoanodes were also fabricated for comparison following a similar procedure except replacing the overlayer $\mathrm{Ni}$ species with the Fe and Co counterparts (Fig. S4).

The PEC-OER performance of the photoanodes was evaluated by measuring cyclic voltammetry (CV) curves in a three-electrode electrochemical system under simulated solar irradiation in aqueous 1.0 M KOH electrolyte (see details in the Experimental Section, Supporting Information). The Fe film thickness dependent PEC performance of the $n^{+} p-S i_{/} / S_{x} / a F e$ photoanodes demonstrates that the $30 \mathrm{~nm}$ Fe film corresponds to the best OER performance, with a typical photocurrent onset potential ( $V_{\text {on }}$, defined as the potential required to achieve an anodic current of $5.5 \mathrm{~mA} \mathrm{~cm}{ }^{-2}$ ) of $\sim 1.22 V_{\mathrm{RHE}}$ and a photocurrent density of $\sim 5.63 \mathrm{~mA} \mathrm{~cm}^{-2}$ at $1.23 V_{\mathrm{RHE}}$, compared to other Fe thicknesses (Fig. S5a, Table S1). After loading MOOH (M =
$\mathrm{Fe}, \mathrm{Co}, \mathrm{Ni}$ ) overlayers on the $\mathrm{n}^{+} \mathrm{p}-\mathrm{Si} / \mathrm{SiO}_{x} / \mathrm{aFe}$, its onset potential shifted cathodically and its photocurrent density increased (Figs. 2a and S5b-d, Table S2), revealing that the overlayer could effectively enhance the OER performance of the $\mathrm{n}^{+} \mathrm{p}-\mathrm{Si} / \mathrm{SiO}_{x} / \mathrm{aFe}$ photoanode. As shown in Fig. 2a, the $\mathrm{n}^{+} \mathrm{p}-\mathrm{Si} / \mathrm{SiO}_{x} / \mathrm{aFe}$ photoanode deposited with the $\mathrm{NiOOH}$ overlayer exhibits the best OER performance compared to the $\mathrm{CoOOH}$ and $\mathrm{FeOOH}$ overlayers (Table S2). The optimized $\mathrm{n}^{+} \mathrm{p}-\mathrm{Si} / \mathrm{SiO}_{x} / \mathrm{aFe}: \mathrm{NiOOH}$ photoanode produced a photocurrent density of $\sim 24.10 \mathrm{~mA} \mathrm{~cm}^{-2}$ at $1.23 V_{\mathrm{RHE}}$ with an onset potential of $\sim 1.01 V_{\text {RHE }}$ and a saturation current density of $\sim 38.82 \mathrm{~mA}$ $\mathrm{cm}^{-2}$ (i.e., $\sim 88.8 \%$ of the crystalline $\mathrm{Si}$ theoretical saturation current density (43.7 $\mathrm{mA} \mathrm{cm}-2$ )). The dark current was near zero (blue dashed curve in Fig. 2a), implying that the observed current under illumination was related to the photogenerated charge carriers. To ensure the reproducibility of the results, over twenty samples were prepared and tested, and the $\mathrm{n}^{+} \mathrm{p}-\mathrm{Si} / \mathrm{SiO}_{x} / \mathrm{aFe} \mathrm{NiOOH}$ photoanode yielded a photocurrent onset potential of $1.01 \pm 0.02 V_{\mathrm{RHE}}$ and a photocurrent density of $\sim 24.10 \pm 2 \mathrm{~mA} \mathrm{~cm}^{-2}$ at $1.23 V_{\mathrm{RHE}}$. The faradaic efficiency of the $\mathrm{n}^{+} \mathrm{p}-\mathrm{Si} / \mathrm{SiO}_{x} / \mathrm{aFe} \mathrm{NiOOH}$ photoanode was measured to be almost $100 \%$, suggesting the efficient splitting of water during the OER process (Fig. 2b). Considering the $100 \%$ faradaic efficiency, the solar-to- $\mathrm{O}_{2}$ conversion efficiency can also be indicated as the applied bias photon-to-current efficiency (ABPE), which reached $3.0 \%$ at $0.95 V_{\mathrm{RHE}}$ (Fig. 2c) for the $\mathrm{n}^{+} \mathrm{p}-\mathrm{Si} / \mathrm{SiO}_{x} / \mathrm{aFe} \mathrm{NiOOH}$ photoanode. The chronoamperometric operation at $1.06 V_{\mathrm{RHE}}$ in $1.0 \mathrm{M} \mathrm{KOH}$ electrolyte was conducted to evaluate the OER stability of the $\mathrm{n}^{+} \mathrm{p}-\mathrm{Si} / \mathrm{SiO}_{x} / \mathrm{aFe}: \mathrm{NiOOH}$ photoanode, which maintains a highly stable photocurrent during the $75 \mathrm{~h}$ stability test (Fig. S6a). The CV curves before and after the stability test show minimal change (Fig. S6b), and there is no distinct change in the morphology of the photoanode after the stability test (Fig. S7), indicating good structure stability of the photoanode. The performance of our $\mathrm{n}^{+} \mathrm{p}-\mathrm{Si} / \mathrm{SiO}_{x} / \mathrm{aFe} \mathrm{NiOOH}$ photoanode is comparable to that of the best reported Si-based photoanodes, as summarized in Table S3.

To explore the underlying mechanism of the OER performance variation in the $n^{+} \mathrm{p}-\mathrm{Si} / \mathrm{SiO}_{x} / \mathrm{aFe}: \mathrm{MOOH}(\mathrm{M}=\mathrm{Ni}, \mathrm{Co}, \mathrm{Fe})$ photoanodes, we first studied the role of the aFe interlayer in the anode. As shown in Fig. S8, the $n^{+} \mathrm{p}-\mathrm{Si} / \mathrm{SiO}_{x} / \mathrm{NiOOH}$ pho-
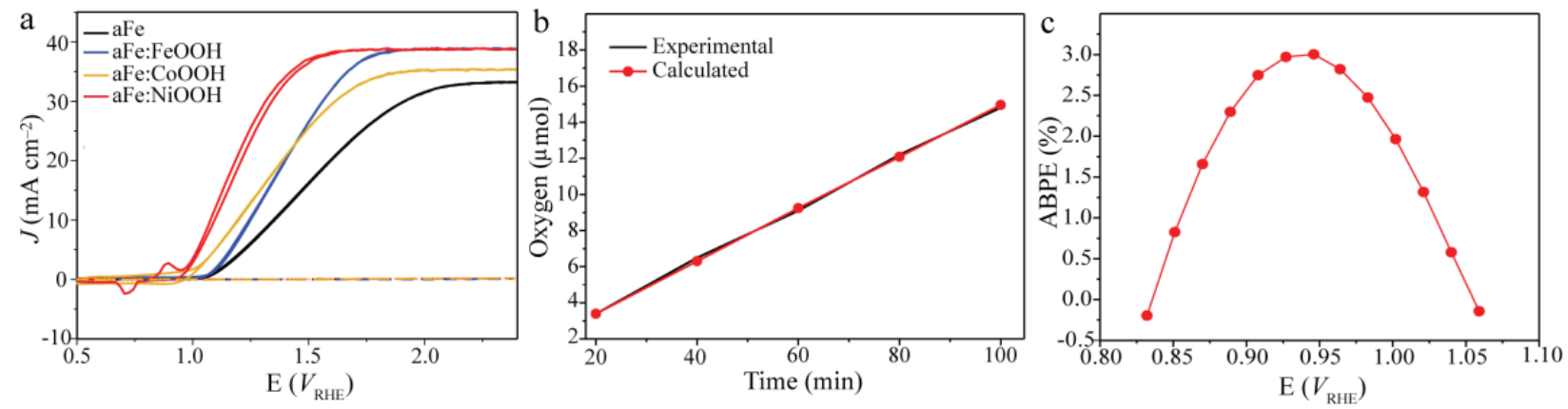

Fig. 2. (a) CV curves of $\mathrm{n}^{+} \mathrm{p}-\mathrm{Si} / \mathrm{SiO}_{x} / \mathrm{aFe}: \mathrm{MOOH}$ photoanodes (dotted lines shows dark conditions: aFe (black); aFe:FeOOH (blue); aFe:CoOOH (yellow); and aFe:NiOOH (red)); (b) $\mathrm{O}_{2}$ production measured (black line) and calculated based on the charge passed assuming $100 \%$ faradaic efficiency (red line); and (c) ABPE for the $\mathrm{n}^{+} \mathrm{p}-\mathrm{Si} / \mathrm{SiO}_{x} / \mathrm{aFe}: \mathrm{NiOOH}$ photoanode conducted in $1 \mathrm{M} \mathrm{KOH}$ electrolyte under illumination at $100 \mathrm{~mW} \mathrm{~cm}^{-2}(\mathrm{AM} 1.5 \mathrm{G})$. 
toanode exhibits a current density of $\sim 0.70 \mathrm{~mA} \mathrm{~cm}^{-2}$ at 1.23 $V_{\mathrm{RHE}}$, a saturation current density of $\sim 13.48 \mathrm{~mA} \mathrm{~cm}^{-2}$, and an onset potential of $\sim 1.20 \quad V_{\mathrm{RHE}}$, which is higher than $\mathrm{n}^{+} \mathrm{p}-\mathrm{Si} / \mathrm{SiO}_{x} / \mathrm{CoOOH}\left(\sim 0.58 \mathrm{~mA} \mathrm{~cm}^{-2}\right.$ at $\left.1.23 V_{\mathrm{RHE}}\right)$ and $\mathrm{n}^{+} \mathrm{p}-\mathrm{Si} / \mathrm{SiO}_{x} / \mathrm{FeOOH}\left(\sim 0.26 \mathrm{~mA} \mathrm{~cm}^{-2}\right.$ at $\left.1.23 V_{\mathrm{RHE}}\right)$. Thus, the OER performance of $\mathrm{n}^{+} \mathrm{p}-\mathrm{Si} / \mathrm{SiO}_{x} / \mathrm{MOOH}$ photoanodes is substantially inferior to that of $\mathrm{n}^{+} \mathrm{p}-\mathrm{Si} / \mathrm{SiO}_{x} / \mathrm{aFe}: \mathrm{MOOH}$ (Fig. 2a and Fig. S8) because they lack appropriate interfacial design. The Fe layer has good adhesion with the $\mathrm{Si}$ surface, and $\mathrm{FeO}_{x}$ has a structure similar to $\mathrm{NiOOH}$, so the aFe interlayer behaves as a bridging interlayer ensuring strong interfacial connection between $\mathrm{Si}$ and the OEC overlayer, which has been well demonstrated in our previous work $[22,23]$. Without the aFe interlayer, it is difficult to integrate the Si substrate with the $\mathrm{NiOOH}$ OEC in a way that takes full advantage of the merits of each constituent to afford good OER activity. Also, aFe can act as a protective layer to ensure the stability of the photoanode. Moreover, Fig. S9 exhibits the electrocatalyst OER behavior of $\mathrm{p}^{++}-\mathrm{Si} / \mathrm{SiO}_{x} / \mathrm{aFe}: \mathrm{MOOH}$ samples with and without the aFe interlayer in the order of aFe:NiOOH $>$ aFe:CoOOH $>$ aFe:FeOOH > $\mathrm{NiOOH}>\mathrm{CoOOH}>\mathrm{FeOOH}$, suggesting that a dual-OEC (aFe:MOOH) shows higher OER performance than a single-OEC $(\mathrm{MOOH})$; that is, aFe plays a key role in electrocatalysis.

Furthermore, thermodynamic (photovoltage) and kinetic (surface catalytic kinetics, surface active sites, and interfacial charge transfer) aspects of the photoanodes with different MOOH overlayers were investigated. For thermodynamics, the photovoltage values of the photoanodes were obtained by measuring the potential difference between the photoanodes under irradiation and a metallic (heavily doped) $\mathrm{p}^{++}-\mathrm{Si}(0.001$ to $0.005 \Omega \mathrm{cm}$ ) coated with the same catalyst layer in the dark (Fig. S10). The results show that the trend in the photovoltage of the $\mathrm{n}^{+} \mathrm{p}-\mathrm{Si} / \mathrm{SiO}_{x} / \mathrm{aFe}: \mathrm{MOOH}$ is inconsistent with that in the OER activity (Table S4), indicating that photovoltage is not the determining factor for the excellent PEC performance of the $\mathrm{n}^{+} \mathrm{p}-\mathrm{Si} / \mathrm{SiO}_{x} / \mathrm{aFe}: \mathrm{NiOOH}$ photoanode. For kinetics, the $\mathrm{n}^{+} \mathrm{p}-\mathrm{Si} / \mathrm{SiO}_{x} / \mathrm{aFe}: \mathrm{MOOH}$ photoanodes for the OER were characterized using Tafel slope, electrochemically active surface area (ECSA), and electrochemical impedance spectroscopy (EIS)
(Fig. 3). The fast electron transfer kinetics, high density of active sites in a specific geometric area, and high conductivity are the key requirements of an efficient OEC. Tafel plots were used to evaluate the OER kinetics and electron transfer [50]. The lower Tafel slope of the $\mathrm{n}^{+} \mathrm{p}-\mathrm{Si} / \mathrm{SiO}_{x} / \mathrm{aFe}: \mathrm{MOOH}$ photoanodes compared to that of the $\mathrm{n}^{+} \mathrm{p}-\mathrm{Si} / \mathrm{SiO}_{x} / \mathrm{aFe}$ photoanode corresponds to the higher OER activity of the $\mathrm{n}^{+} \mathrm{p}-\mathrm{Si} / \mathrm{SiO}_{x} / \mathrm{aFe}: \mathrm{MOOH}$, suggesting the vital contribution of OEC overlayers to OER kinetics (Fig. 3a, Table S4). Moreover, the $\mathrm{n}^{+} \mathrm{p}-\mathrm{Si} / \mathrm{SiO}_{x} / \mathrm{aFe}: \mathrm{NiOOH}$ photoanode has the smallest Tafel slope $\left(85 \mathrm{mV} \mathrm{dec}^{-1}\right)$ when compared to the $\mathrm{n}^{+} \mathrm{p}-\mathrm{Si} / \mathrm{SiO}_{x} / \mathrm{aFe}: \mathrm{CoOOH} \quad\left(88 \mathrm{mV} \quad \mathrm{dec}^{-1}\right)$ and the

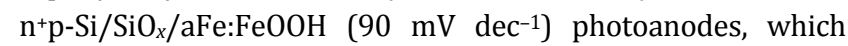
suggests more efficient OER kinetics in the $\mathrm{n}^{+} \mathrm{p}-\mathrm{Si} / \mathrm{SiO}_{x} / \mathrm{aFe} \mathrm{NiOOH}$ photoanode. ECSA was then tested to better understand the number of catalytically active sites for OER activity. The scan-rate dependent electrochemical double-layer charge capacitance evaluated from $\mathrm{CV}$ scans of the $\mathrm{n}^{+} \mathrm{p}-\mathrm{Si} / \mathrm{SiO}_{x} / \mathrm{aFe}: \mathrm{NiOOH}$ photoanode is $0.298 \mathrm{mF} \mathrm{cm}^{-2}$, which is higher than those of the $\mathrm{n}^{+} \mathrm{p}-\mathrm{Si} / \mathrm{SiO}_{x} / \mathrm{aFe}: \mathrm{CoOOH}(0.241 \mathrm{mF}$ $\mathrm{cm}^{-2}$ ) and $\mathrm{n}^{+} \mathrm{p}-\mathrm{Si} / \mathrm{SiO}_{x} / \mathrm{aFe}: \mathrm{FeOOH}\left(0.209 \mathrm{mF} \mathrm{cm}^{-2}\right.$ ) (Fig. 3b) photoanodes, which is also consistent with the intrinsic activity of the OEC (Table S4).

Finally, the $\mathrm{n}^{+} \mathrm{p}-\mathrm{Si} / \mathrm{SiO}_{x} / \mathrm{aFe}: \mathrm{MOOH}$ photoanodes were investigated using EIS. The Nyquist plots of all Si photoanodes were acquired at $1.23 V_{\text {RHE }}$ under AM 1.5G sunlight illumination (Fig. 3c) and fitted to the equivalent circuit shown in the Fig. 3c inset, where $R_{1}$ and $R_{2}$ of the circuit were assigned to the resistances of charge transfer in the bulk photoanode and at the photoanode/electrolyte interface, respectively. The MOOH overlayer significantly reduces $R_{2}$ of the $\mathrm{n}^{+} \mathrm{p}-\mathrm{Si} / \mathrm{SiO}_{x} / \mathrm{aFe}$ photoanode, suggesting that water oxidation proceeds much more easily on the surface of the $\mathrm{n}^{+} \mathrm{p}-\mathrm{Si} / \mathrm{SiO}_{x} / \mathrm{aFe}: \mathrm{MOOH}$ photoanode than on bare $n^{+} p-S i / S_{0} / a F e$, which can be reflected by the small diameter of the semicircle in the low-frequency region. Both reduced charge transfer resistances $\left(R_{1}\right.$ and $\left.R_{2}\right)$ suggest that photogenerated holes can be injected into the electrolyte, and fast photo-driven charge transfer processes for water oxidation occur more rapidly at the $\mathrm{n}^{+} \mathrm{p}-\mathrm{Si} / \mathrm{SiO}_{x} / \mathrm{aFe}: \mathrm{MOOH}$ pho-
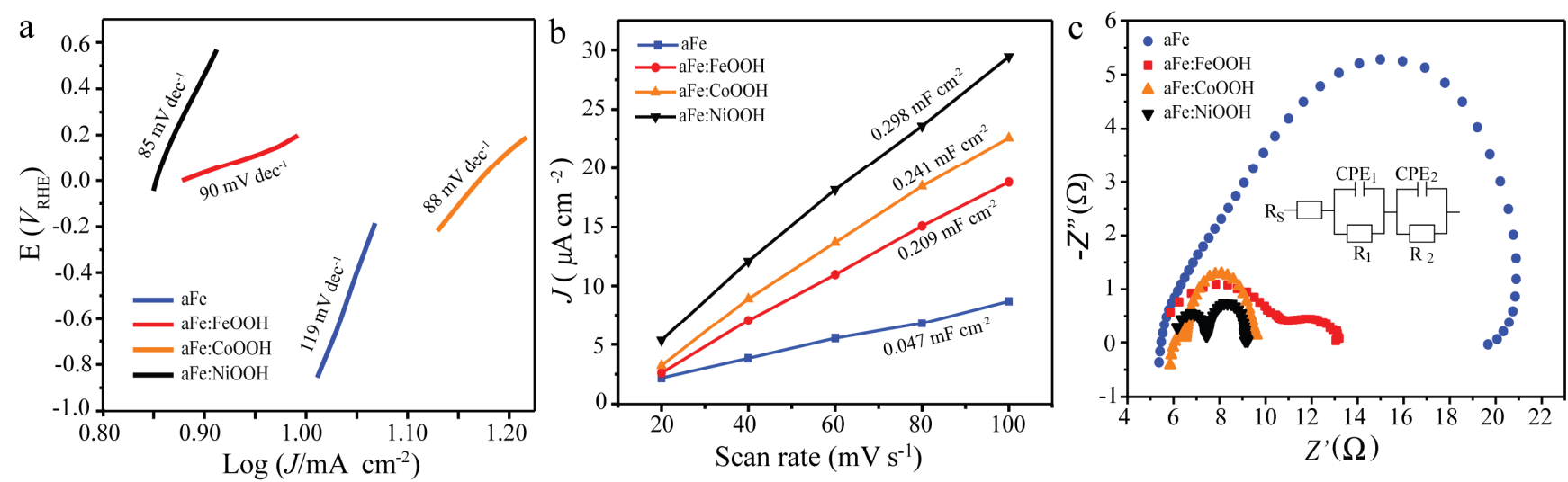

Fig. 3. (a) Tafel plots extracted from the current density-voltage (J-V) measurements at a scan rate of $50 \mathrm{mV} \mathrm{s}^{-1}$; (b) Capacitive currents at different scan rates (The linear slope, equivalent to twice of the double-layer capacitance $C_{d l}$, is used to represent the ECSA); and (c) impedance Nyquist plots measured at $1.23 V_{\mathrm{RHE}}$ for the $\mathrm{n}^{+} \mathrm{p}-\mathrm{Si} / \mathrm{SiO}_{x} / \mathrm{aFe}$ photoanodes with and without the MOOH overlayer for experiments conducted in $1 \mathrm{M} \mathrm{KOH}$ under irradiation at $100 \mathrm{~mW} \mathrm{~cm}^{-2}(\mathrm{AM} 1.5 \mathrm{G})$. 
toanode due to the presence of a MOOH overlayer (Table S4) [32]. This result demonstrates that the MOOH overlayer significantly increases the OER performance through accelerating the charge transfer both at the photoanode/electrolyte interface and in the bulk photoanode. The $\mathrm{n}^{+} \mathrm{p}-\mathrm{Si} / \mathrm{SiO}_{x} / \mathrm{aFe}: \mathrm{NiOOH}$ photoanode shows a remarkably small resistance $(2.95 \Omega)$ in both bulk charge transfer and charge transfer at the photoanode/electrolyte interface when compared to the $\mathrm{n}^{+} \mathrm{p}-\mathrm{Si} / \mathrm{SiO}_{x} / \mathrm{aFe}: \mathrm{CoOOH} \quad(3.86 \quad \Omega) \quad$ and the $\mathrm{n}^{+} \mathrm{p}-\mathrm{Si} / \mathrm{SiO}_{x} / \mathrm{aFe}: \mathrm{FeOOH}$ (7.19 $\Omega$ ) photoanodes (Table S4), leading to the efficient interfacial charge transfer for enhanced OER activity (Fig. 2). Therefore, the overall results (CV, Tafel slope, ECSA, and EIS) are consistent with the OER activity of the corresponding photoanodes, and it can be concluded that the aFe:NiOOH dual-OEC on $\mathrm{n}^{+} \mathrm{p}-\mathrm{Si} / \mathrm{SiO}_{x}$ promotes more charge transport and charge separation (Fig. S11), provides larger number of surface active sites, and higher intrinsic OER activity, compared to other OECs.

Taken together, the performance for our photoanodes can be understood as follows. The PEC performance of a photoanode is determined simultaneously by thermodynamic (photovoltage) and kinetic (surface catalytic kinetics, surface active sites, and interfacial charge transfer) factors. In our case, the photovoltage is excluded as the determining factor, and the kinetics is confirmed as the cause of the variation in the PEC OER activity for the $\mathrm{n}^{+} \mathrm{p}-\mathrm{Si} / \mathrm{SiO}_{x} / \mathrm{aFe}$ and $\mathrm{n}^{+} \mathrm{p}-\mathrm{Si} / \mathrm{SiO}_{x} / \mathrm{aFe}: \mathrm{MOOH}$ photoanodes. The superior PEC activity of the $\mathrm{n}^{+} \mathrm{p}-\mathrm{Si} / \mathrm{SiO}_{x} / \mathrm{aFe}: \mathrm{MOOH}$ photoanode is a result of it having the most favorable kinetics compared to those of other photoanodes due to its optimal interface engineering, which promotes charge transport, provides larger number of surface active sites, and has higher intrinsic OER activity.

\section{Conclusions}

In conclusion, we have systematically investigated the effect of the transition-metal OECs on the PEC-OER activity of the Si-based photoanodes. Our experimental results indicate that interfacial engineering of electrocatalysts will greatly improve the performance by promoting interfacial charge transport, providing a large number of surface active sites, and increasing OER activity. We believe that this study will be beneficial for the design and fabrication of high-performance solar energy conversion devices.

\section{Electronic supporting information}

Experimental details, fabrication of photoanodes, characterizations, XPS survey spectra, Raman spectra, SEM images, PEC measurements, electrochemical measurements, and Si-based photoanode materials comparison list are available in the online supporting information.

\section{References}

[1] M. G. Walter, E. L. Warren, J. R. McKone, S. W. Boettcher, Q. Mi, E. A. Santori, N. S. Lewis, Chem. Rev., 2010, 110, 6446-6473.
[2] Z. Chen, Q. Huang, B. Huang, F. Zhang, C. Li, Chin. J. Catal., 2019, 40, 38-42.

[3] P. Kuang, B. Zhu, Y. Li, H. Liu, J. Yu, K. Fan, Nanoscale Horiz., 2018, 3, 317-326.

[4] P. Li, W. Chen, Chin. J. Catal., 2019, 40, 4-22.

[5] P. Kuang, M. He, H. Zou, J. Yu, K. Fan, Appl. Catal. B, 2019, 254, 15-25.

[6] X. Li, J. Yu, M. Jaroniec, X. Chen, Chem. Rev., 2019, 119, 3962-4179.

[7] R. Shen, J. Xie, Q. Xiang, X. Chen, J. Jiang, X. Li, Chin. J. Catal., 2019, 40, 240-288.

[8] W. Zhang, H. Zhang, J. Xu, H. Zhuang, J. Long, Chin. J. Catal., 2019, 40, 320-325.

[9] K. He, J. Xie, X. Luo, J. Wen, S. Ma, X. Li, Y. Fang, X. Zhang, Chin. J. Catal., 2017, 38, 240-252.

[10] S. Hu, M. R. Shaner, J. A. Beardslee, M. Lichterman, B. S. Brunschwig, N. S. Lewis, Science, 2014, 344, 1005-1009.

[11] M. J. Kenney, M. Gong, Y. Li, J. Z. Wu, J. Feng, M. Lanza, H. Dai, Science, 2013, 342, 836-840.

[12] A. G. Scheuermann, J. P. Lawrence, K. W. Kemp, T. Ito, A. Walsh, C. E. Chidsey, P. K. Hurley, P. C. McIntyre, Nat. Mater., 2016, 15, 99-105.

[13] G. Xie, S. U. Jan, Z. Dong, Y. Dai, R. Boddula, Y. Wei, C. Zhao, Q. Xin, J.-N. Wang, Y. Du, Chin. J. Catal., 2020, 41, 2-8.

[14] J. Yang, K. Walczak, E. Anzenberg, F. M. Toma, G. Yuan, J. Beeman, A. Schwartzberg, Y. Lin, M. Hettick, A. Javey, J. Am. Chem. Soc., 2014, 136, 6191-6194.

[15] Y. W. Chen, J. D. Prange, S. Dühnen, Y. Park, M. Gunji, C. E. Chidsey, P. C. McIntyre, Nat. Mater., 2011, 10, 539-544.

[16] B. Mei, B. Seger, T. Pedersen, M. Malizia, O. Hansen, I. Chorkendorff, P. C. Vesborg, J. Phys. Chem. Lett., 2014, 5, 1948-1952.

[17] M. Mikolasek, K. Frohlich, K. Husekova, J. Racko, V. Rehacek, F. Chymo, M. Tapajna, L. Harmatha, Appl. Surf. Sci., 2018, 461, 48-53.

[18] J. Yang, D. Wang, H. Han, C. Li, Acc. Chem. Res., 2013, 46, 1900-1909.

[19] I. A. Digdaya, G. W. Adhyaksa, B. J. Trześniewski, E. C. Garnett, W. A. Smith, Nat. Commun., 2017, 8, 15968/1-15968/8.

[20] X. Zhou, R. Liu, K. Sun, K. M. Papadantonakis, B. S. Brunschwig, N. S. Lewis, Energy Environ. Sci., 2016, 9, 892-897.

[21] R. Fan, Z. Mi, M. Shen, Opt. Express, 2019, 27, A51-A80.

[22] B. Guo, A. Batool, G. Xie, R. Boddula, L. Tian, S. U. Jan, J. R. Gong, Nano Lett., 2018, 18, 1516-1521.

[23] R. Boddula, B. Guo, A. Ali, G. Xie, Y. Dai, C. Zhao, Y. Wei, S. U. Jan, J. R. Gong, ACS Appl. Energy Mater., 2019, 2, 7256-7262.

[24] K. Sun, S. Shen, Y. Liang, P. E. Burrows, S. S. Mao, D. Wang, Chem. Rev., 2014, 114, 8662-8719.

[25] L. Trotochaud, S. L. Young, J. K. Ranney, S. W. Boettcher, J. Am. Chem. Soc., 2014, 136, 6744-6753.

[26] B. M. Hunter, H. B. Gray, A. M. Muller, Chem. Rev., 2016, 116, 14120-14136.

[27] Y. Hou, X. Zhuang, X. Feng, Small Methods, 2017, 1, 1700090.

[28] C. Li, Y. Xiao, L. Zhang, Y. Li, J.-J. Delaunay, H. Zhu, Sustain. Energy Fuels, 2018, 2, 663-672.

[29] A. Singh, L. Spiccia, Coord. Chem. Rev., 2013, 257, 2607-2622.

[30] N. Wang, H. Zheng, W. Zhang, R. Cao, Chin. J. Catal., 2018, 39, 228-244.

[31] F. A. Laskowski, M. R. Nellist, J. Qiu, S. W. Boettcher, J. Am. Chem. Soc., 2018, 141, 1394-1405.

[32] J. Y. Kim, D. H. Youn, K. Kang, J. S. Lee, Angew. Chem. Int. Ed., 2016, 55, 10854-10858.

[33] W. D. Chemelewski, H.-C. Lee, J.-F. Lin, A. J. Bard, C. B. Mullins, J. 


\section{Graphical Abstract}

Chin. J. Catal., 2021, 42: 1387-1394 doi: 10.1016/S1872-2067(20)63647-6

Role of transition-metal electrocatalysts for oxygen evolution with Si-based photoanodes

Rajender Boddula, Guancai Xie, Beidou Guo, Jian Ru Gong*

National Center for Nanoscience and Technology; University of Chinese Academy of Sciences
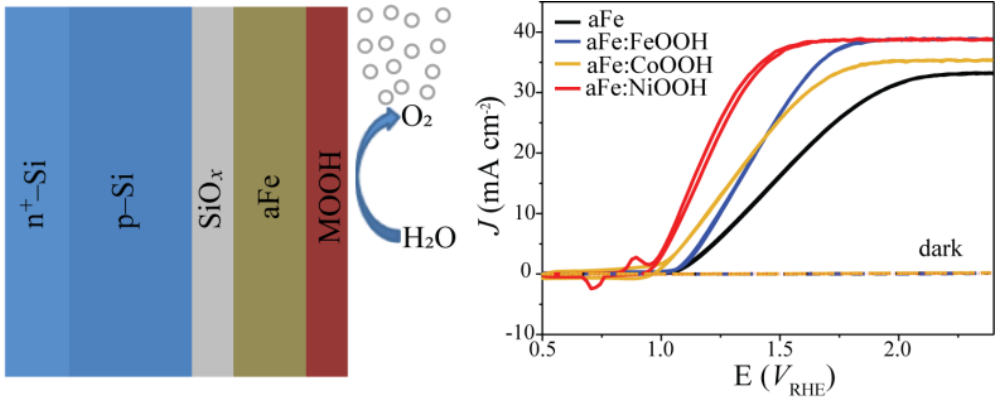

The $\mathrm{n}^{+} \mathrm{p}-\mathrm{Si} / \mathrm{SiO}_{x} / \mathrm{aFe}: \mathrm{NiOOH}$ photoanode exhibits the best oxygen evolution performance due to its optimal interfacial engineering for transition-metal electrocatalysts.

Am. Chem. Soc., 2014, 136, 2843-2850.

[34] T. W. Kim, K.-S. Choi, Science, 2014, 343, 990-994.

[35] T. Yao, R. Chen, J. Li, J. Han, W. Qin, H. Wang, J. Shi, F. Fan, C. Li, J. Am. Chem. Soc., 2016, 138, 13664-13672.

[36] J. C. Hill, A. T. Landers, J. A. Switzer, Nat. Mater., 2015, 14, 1150-1155.

[37] D. Bae, B. Mei, R. Frydendal, T. Pedersen, B. Seger, O. Hansen, P. C. Vesborg, I. Chorkendorff, ChemElectroChem, 2016, 3, 1546-1552.

[38] S. Oh, S. Jung, Y. H. Lee, J. T. Song, T. H. Kim, D. K. Nandi, S.-H. Kim, J. Oh, ACS Catal., 2018, 8, 9755-9764.

[39] K. Sun, M. T. McDowell, A. C. Nielander, S. Hu, M. R. Shaner, F. Yang, B. S. Brunschwig, N. S. Lewis, J. Phys. Chem. Lett., 2015, 6, 592-598.

[40] I. Roger, M. D. Symes, J. Mater. Chem. A, 2016, 4, 6724-6741.

[41] Y. Kuang, Q. Jia, H. Nishiyama, T. Yamada, A. Kudo, K. Domen, Adv. Energy Mater., 2016, 6, 1501645.

[42] Y.-J. Shih, Y.-H. Huang, C. Huang, Electrochim. Acta, 2018, 263,
261-271.

[43] Q. Cai, W. Hong, C. Jian, J. Li, W. Liu, ACS Catal., 2017, 7, 3277-3283.

[44] S. Klaus, Y. Cai, M. W. Louie, L. Trotochaud, A. T. Bell, J. Phys. Chem. C, 2015, 119, 7243-7254.

[45] L. Trotochaud, J. K. Ranney, K. N. Williams, S. W. Boettcher, J. Am. Chem. Soc., 2012, 134, 17253-17261.

[46] L. Cai, J. Zhao, H. Li, J. Park, I. S. Cho, H. S. Han, X. Zheng, ACS Energy Lett., 2016, 1, 624-632.

[47] H. Zhou, F. Yu, Q. Zhu, J. Sun, F. Qin, L. Yu, J. Bao, Y. Yu, S. Chen, Z. Ren, Energy Environ. Sci., 2018, 11, 2858-2864.

[48] D. Tang, O. Mabayoje, Y. Lai, Y. Liu, C. B. Mullins, ChemistrySelect, 2017, 2, 2230-2234.

[49] J. Li, S. Jiang, M. Shao, M. Wei, Catalysts, 2018, 8, 214.

[50] T. Shinagawa, A. T. Garcia-Esparza, K. Takanabe, Sci. Rep., 2015, 5, 13801.

\section{过渡金属电催化剂在硅基光阳极分解水产氧中的作用}

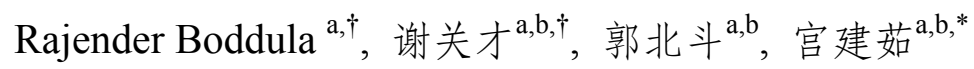

a国家纳米科学中心, 中国科学院纳米系统与多级次重点实验室, 中国科学院纳米科学卓越创新中心, 北京 100190

b 中国科学院大学, 北京 100049

摘要: 光电化学分解水可将太阳能转换为绿色的氢能, 为目前的能源危机和环境问题提供了一种理想的解决方案. 在分解 水反应中, 涉及四空穴过程的产氧半反应是制约性能的关键步骤, 往往需要在半导体表面沉积电催化剂以加速产氧反应动 力学. 因此, 全面理解电催化剂在光电化学分解水体系中的作用至关重要. 在目前的产氧电催化剂中, 过渡金属羟基氧化 物电催化剂( $\mathrm{MOOH}, \mathrm{M}=\mathrm{Fe}, \mathrm{Co}, \mathrm{Ni})$ 因其环保、廉价、高效以及稳定的特性, 已被广泛用于半导体光阳极分解水器件中. 而 且, MOOH可用简单的电沉积方法沉积在光电极表面, 易于大面积制备. 然而, 电沉积法制备的MOOH具有复杂的结构, 对 其作用机制的全面理解更加困难. 因此, 本文以电沉积 $\mathrm{MOOH}$ 修饰的硅基光阳极 $\left(\mathrm{n}^{+} \mathrm{p}-\mathrm{Si} / \mathrm{SiO}_{x} / \mathrm{Fe} / \mathrm{FeO} x / \mathrm{MOOH}\right)$ 作为模型, 研 究了不同电催化剂对硅光阳极光电化学产氧性能的影响. 实验发现电催化剂的界面优化在电催化剂修饰的光电极中发挥 着重要作用, 这是因为优化的界面可以提升界面电荷传输, 提供更多的催化反应活性位点以及更高的本征催化活性, 从而 更有利于光解水性能的提升. 该项研究揭示了电催化剂在光解水器件中的作用, 并为今后高效光解水器件的设计提供了 
一定指导.

首先在多晶 $\mathrm{n}^{+} \mathrm{p}-\mathrm{Si}$ 基底上热蒸镀了一层 $30 \mathrm{~nm}$ 的金属 $\mathrm{Fe}$ 膜, 并通过电化学活化将 $\mathrm{Fe}$ 膜表面转换为 $\mathrm{FeO}_{x}$ 得到 $\mathrm{Fe} / \mathrm{FeO}$ ( 记 作 $\mathrm{aFe}$ ) 界面层, 然后利用电沉积方法制备 $\mathrm{MOOH}$ 表面修饰层, 最终得到 $\mathrm{n}^{+} \mathrm{p}-\mathrm{Si} / \mathrm{SiO}_{x} / \mathrm{aFe}: \mathrm{MOOH}$ 光阳极. X射线光电子能谱、 拉曼光谱以及扫描电子显微镜表面元素成像的表征结果均证实电极表面由于界面层金属 $\mathrm{Fe}$ 元素的掺杂而形成了 $\mathrm{Fe}_{1-\mathrm{x}} \mathrm{Ni}_{x} \mathrm{OOH}$. 在模拟太阳光下用于光解水产氧时, $\mathrm{n}^{+} \mathrm{p}-\mathrm{Si} / \mathrm{SiO}_{x} / \mathrm{aFe}: \mathrm{NiOOH}$ 电极的起始电位为 $1.01 \mathrm{~V}_{\mathrm{RHE}}$ (相对于可逆氢电 极的电势), 在 $1.23 \mathrm{~V}_{\mathrm{RHE}}$ 下的光电流为 $38.82 \mathrm{~mA} \mathrm{~cm}{ }^{-2}$, 显著优于 $\mathrm{n}^{+} \mathrm{p}-\mathrm{Si} / \mathrm{SiO}_{x} / \mathrm{aFe} 、 \mathrm{n}^{+} \mathrm{p}-\mathrm{Si} / \mathrm{SiO}_{x} / \mathrm{aFe}: \mathrm{FeOOH}$ 以及 $\mathrm{n}^{+} \mathrm{p}-\mathrm{Si} / \mathrm{SiO}_{x} / \mathrm{aFe}: \mathrm{CoOOH}$ 三个对比样品, 且其稳定性达到 $75 \mathrm{~h}$. 另外, 我们发现 ${ }^{+} \mathrm{p}-\mathrm{Si} / \mathrm{SiO}_{x} / \mathrm{aFe}: \mathrm{MOOH}$ 电极的光电化学产氧性 能均显著高于 $\mathrm{n}^{+} \mathrm{p}-\mathrm{Si} / \mathrm{SiO}_{x} / \mathrm{aFe}$ 电极, 且 ${ }^{++}{ }_{-} \mathrm{Si} / \mathrm{SiO}_{x} / \mathrm{aFe}: \mathrm{MOOH}$ 的电催化产氧性能也高于 $\mathrm{p}^{++}-\mathrm{Si} / \mathrm{SiO}_{x} / \mathrm{MOOH}$, 不仅证明了 $\mathrm{aFe}$ 界 面层对 $\mathrm{Si}$ 与 $\mathrm{MOOH}$ 层之间的界面接触作用的有效调控, 而且表明双电催化剂体系 $(\mathrm{aFe}: \mathrm{MOOH})$ 的电催化产氧活性高于单电 催化剂 $(\mathrm{MOOH})$. 热力学分析表明, $\mathrm{n}^{+} \mathrm{p}-\mathrm{Si} / \mathrm{SiO}_{x} / \mathrm{aFe}: \mathrm{MOOH}$ 光阳极的光电压大小与其光解水产氧性能并不一致, 从而排除了 热力学因素对性能的关键影响. 进一步从塔菲尔斜率、电化学活性表面积和电化学阻抗谱对各电极的动力学进行了分析, 证明了动力学因素在上述光阳极产氧性能中的主导作用. 同时发现, 由于 $\mathrm{aFe}: \mathrm{NiOOH}$ 双电催化剂具有更高的本征电催化产 氧性能, 提供了更多的表面活性位点以及更有效地促进了光生载流子的传输, 对动力学的提升效果更显著, 从而使 $\mathrm{n}^{+} \mathrm{p}-\mathrm{Si} / \mathrm{SiO}_{x} / \mathrm{aFe}: \mathrm{NiOOH}$ 光阳极表现出最高的光解水产氧性能.

关键词: 光解水; 人工光合作用; 产氧反应; 光阳极; 界面工程; 过渡金属电催化剂

收稿日期: 2020-02-28. 接受日期: 2020-03-23. 上网时间: 2021-04-05.

*通讯联系人. 电话: (010)82545649; 传真: (010)62656765; 电子信箱: gongji@nanoctr.cn

†共同第一作者.

基金来源：中国科学院战略性先导科技专项(B类)资助(XDB36000000); 国家自然科学基金(21422303, 21573049, 21872043, 22002028); 北京市自然科学基金(2142036); 中国科学院青年创新促进会; 中国科学院“一带一路”专项; 中国科学院“国际人才计 划”.

本文的电子版全文由Elsevier出版社在ScienceDirect上出版(http://www.sciencedirect.com/journal/chinese-journal-of-catalysis). 